\title{
Investigation of the Studies Published on WOS between 2014-2018 in the Field of Violence to Health Employees Worldwide
}

\author{
Dünya Genelinde Sağlık Çalışanlarına Şiddet Alanında 2014-2018 Yılları Arasında Web \\ of Science'ta Taranan Çalışmaların İncelenmesi
}

\author{
Elif Nisa YAYLA ${ }^{1}$
}

ÖZ

Bu çalışmada, sağlık çalışanlarına şiddet alanında son beş yılda (2014-2018) Web of Science’ta (WOS) taranan çalışmaların farklı değişkenler açısından incelenmesi amaçlanmıştır. Araştırmanın evrenini WOS veri tabanı kapsamında bulunan, 2014'ten 2018'e kadar yapılmıș ve başlıklarında "violence health workers", "verbal abuse health workers", "physical violence health workers", "sexual harassment health workers" ve "cyberbullying health workers" kelimelerini bulunduran çalışmalar oluşturmaktadır. Çalışmaya araştırma türü, "araştırma makalesi”" olmayan yayınlar dahil edilmemiştir. Yapılan analiz sonucunda toplam 90 makale olduğu saptanmış, bunlardan 85 tanesine ulaşılmış ve bazı kriterler belirlenerek incelenmiştir. Çalışmalara en fazla "violence against health workers" anahtar kelimesi kullanılarak ulaşılmış ve ulaşılan çalışmaların en çok 2017 yılında (30) ve İngilizce (74) dilinde yayınlandığ saptanmıştır. Çalışmaların en fazla altı yazarlı ve üstü (26) olduğu ve yazarların en fazla Sağlık, İşletme ve Yönetim ile ilgili bölümlerde görev yaptığı bulunmuştur. Sağlık çalışanlarına şiddet alanındaki çalışmalar sırasıyla en fazla ABD (15), Türkiye (9), Çin (9) ve İtalya (7)'da yapılmıştır. İncelenen çalışmalarda araştırma yöntemi olarak en fazla nicel yöntem (44), veri toplama aracı olarak ise anket (48) ve odak grup görüşmesi / derinlemesine görüşme / görüşme tekniği (16) kullanılmıştır.

Anahtar Kelimeler: Araştırma Makalesi, Sağlık Çalışanları, Web of Science, Şiddet.

\begin{abstract}
The aim of this study, is to examine studies searched on WOS ( Web of Science) in the field of violence to health employees worldwide in the last five years in terms of different variables. The study's universe is made up of the WOS databases from 2014 to 2018 and includes studies with the words "violence health workers", "verbal abuse health workers", "physical violence health workers", "sexual harassment health workers" and "cyberbullying health workers". Only "research articles" were examined. In total 90 articles were identified, of which 85 were reached and examined according to criteria determined by the researchers. In the studies, which is reached as full text, "violence against health workers" was the most commonly used keyword. It was determined that the studies were mostly published in 2017 (30) and English (74) was the commonly preferred language of the studies. It has been found that the studies conducted are mostly written by two authors and above (26) and the authors of all 84 studies mostly work in departments related to Health and Business Administration. Studies in the field of violence to health employees were made mostly in ABD (15), Turkey (9), China (9) ve Italy (7), respectively. In the studies examined, survey (48) and focus group interview / deep interview / interview technique (16) was used as a data collection tools and quantitative method (44) was used as the research method.
\end{abstract}

Keywords: Research articles, Violence, Health employees, Web of Science.

\section{LITERATURE REVIEW}

Although there has been an increase in all types of violence, which came into being with the existence of humanity, in the lives of all nations, in all professions, ages and ethnic societies, and in all parts of the world today, it has become increasingly important especially at workplaces (1).

Ca. $25 \%$ of the total violence cases at workplaces are observed in the healthcare sector; and more than $50 \%$ of healthcare staff report that they are subjected to violence

\footnotetext{
${ }^{1}$ Kayseri Üniversitesi, Sosyal Bilimler Meslek Yüksekokulu,

Sağlık Kurumları İşletmeciliği

e-posta: elifnisayayla@kayseri.edu.tr
} 
at any time when they are practicing their profession $(2,3)$. Providing 24-hour non-stop service in healthcare facilities, the work intensity, the presence of stressful patient relatives, long waiting periods, insufficient benefit from services, insufficient number of staff, working in crowded workplaces, insufficient education, insufficient number of security staff, and the absence of a restriction against violence may increase the risk of violence (4). All these aside, there are several biological, social learning, and injury-aggression theories explaining violence. In the biological theory, a medical approach is valid about violence, while social learning theory argues that violence is learned later. According to the injury-aggression theory, violence is a response to an injury that occurs as a result of not fulfilling important expectations. This theory may explain the violent behaviors faced in healthcare institutions (8).

It was observed that some units are riskier than other units in hospitals in terms of violence. Emergency units, surgery clinics, primary care wards, psychiatry clinics, oncology, intensive care units and outpatient clinics were reported as the most frequent incidents of violence (9). As a result of the physical, verbal, sexual and cyber violence, negative psychological effects occur on the staff, their family members, and eye witnesses; $(5,6)$ and economic costs that cannot be estimated and loss of working days occur (7). In addition, the quality of services provided by the healthcare staff to another patient decreases in an indirect manner after healthcare staff face violence (8).

For the purpose of coping with violence, small-scale measures may be taken at patient-employee level, as well as large-scale measures that concern the hospital. Conventional measures (like restraints, isolations and medications) cause reactive situations, increase the stress of the staff, and reduce patient-employee relations (8).

The increasing incidents of violence in healthcare staff and their increasing importance in recent years gave rise to academic studies on this subject. According to the internationally accepted common consensus, the number of publications in international scientific indices like SCI, SSCI, AHCI is used as a criterion in the evaluation of academics and disciplines; and they also demonstrate the scientific performance of countries. With the present study, the purpose was to examine the publications in the field of violence in healthcare journals in the Web of Science database; and to cast light on the evaluation of current situation.

\section{METHOD}

In this study, it is aimed at examining the studies published on the Web of Science (WOS) in the last five years (20142018) in the field of violence to health employees from the perspective of difference variables. The universe of the research comprises the studies which were carried out between 2014-2018 under the scope of WOS database, with titles containing the keywords "violence health workers", "verbal abuse health workers", "physical violence health workers", "sexual harassment health workers" and "cyberbullying health workers". The keywords were selected based on the types of violence as grouped by Polat (2017) (5). In the study, publications whose research type is not a "research article" were excluded from the scope.

Articles used in the study were acquired from WOS database in February 2019. As a result of the analysis conducted, it was found out that there were a total of 90 articles authored in the last five years in the field of violence to health employees in WOS database. 85 of these articles were accessed, and the articles were studied from the point of such criteria as the year of the study, number of persons who performed the study, method of the study, country in which the study is conducted, keywords, and in which sections the authors contributed in violence to health employees.

Since the full text of five articles were not accessed under the scope of the study, only the abstracts of the articles were analyzed. The fact that the information in the abstract part was insufficient lead to leaving some criteria aimed to be studied empty. Besides, the fact that no access could be provided over IP (internet protocol) of Erciyes University to 85 out of 90 articles in total constituted the limitations of the research.

\section{FINDINGS}

In the study, researches published on the WOS in the last five years (2014-2018) in the field of violence to health employees between 2014-2018, were examined from the point of different variables. It was determined that there were a total of 90 articles written in the last five years in the field of violence to health employees. 85 of these were reached and studied. 
Table 1: Distribution of Articles by Years

\begin{tabular}{lll}
\hline Year of Publication & N & $\mathbf{\%}$ \\
\hline 2014 & 4 & 4,70 \\
\hline 2015 & 13 & 15,29 \\
\hline 2016 & 13 & 15,29 \\
\hline 2017 & 30 & 35,29 \\
\hline TOTAL & 25 & 29,41 \\
\hline
\end{tabular}

Table 1 shows the distribution of articles by years. When the articles under the research scope are examined over years, it was found that the maximum number of studies in the field of violence to health employees was published in 2017 (30).

Table 2: Distribution of Articles by Languages Used

\begin{tabular}{lll}
\hline Languages Used & N & $\mathbf{\%}$ \\
\hline English & 78 & 91,76 \\
\hline Spanish & 4 & 4,70 \\
\hline Other (Italian, Korean, Hungarian ..) & 3 & 8,23 \\
\hline TOTAL & $\mathbf{8 5}$ & $\mathbf{1 0 0 , 0}$ \\
\hline
\end{tabular}

Table 2 shows the distribution of articles by languages used. When we look at the language used in the articles studied, we see that the highest number of articles in the five years in violence to health employees were in English (78), follows by Spanish (4). Other articles include one for each of Italian Korean and Hungarian languages.

Table 3: Distribution of Articles By Number of Authors

\begin{tabular}{lll}
\hline Number of Persons Who Conducted the Study & N & $\mathbf{\%}$ \\
\hline 1author & 7 & 8,33 \\
\hline 2 authors & 12 & 14,28 \\
\hline 3 authors & 17 & 20,23 \\
\hline 4 authors & 16 & 19,04 \\
\hline 5 authors & 7 & 8,33 \\
\hline 6 and above & 25 & 29,76 \\
\hline TOTAL & $\mathbf{8 4}$ & $\mathbf{1 0 0 , 0}$ \\
\hline
\end{tabular}

Table 3 shows the distribution of articles by the number of authors. When the articles studied are evaluated according to the number of authors, it could be seen that there were 25 articles with 6 and above authors, followed by 17 with 3 authors and 16 with 4 authors.

Table 4: Distribution of Articles by Keywords

\begin{tabular}{lll}
\hline Keywords & N & $\mathbf{\%}$ \\
\hline Violence Health Workers & 60 & 70,58 \\
\hline Verbal Abuse Health Workers & 6 & 7,05 \\
\hline Physical Violence Health Workers & 8 & 9,41 \\
\hline Sexual Harassment Health Workers & 8 & 9,41 \\
\hline Cyberbullying Health Workers & 3 & 3,52 \\
\hline TOTAL & $\mathbf{8 5}$ & $\mathbf{1 0 0}$ \\
\hline
\end{tabular}

Table 4 shows the distribution of articles by keywords. It could be seen that the highest number of keywords in the last five years was 60 for "Violence Health Workers", which is followed by "Sexual Harassment Health Workers" and "Physical Violence Health Workers" with 8, and "Verbal Abuse Health Workers" with 6.

In the studied conducted, it was found that the authors were mainly working in the departments related to Health and Business Administration. Studies in the field of violence to health employees were mostly carried out in ABD (15), Turkey (9), China (9) ve Italy (7). As the research method, quantitative method (44) were used the most. And as the data collection tools, survey (48) and focal group interview / in-depth interview / interview techniques (16) were used the most.

\section{DISCUSSION, CONCLUSION AND RECOMMENDATIONS}

This widespread use of violence against health workers has increased the importance of this issue in recent years. This has enabled this issue's academic studies to be carried out.

When the distribution of researches over years was studied, it could be seen that the highest number was 30 in 2017.There are 30 studies in the previous years (total of 2014, 2015 and 2016). Until 2018, 50\% of the studies conducted in the field of violence to health workers were made in 2017. By looking at it, it can be said that the interest shown to the health workers in the field of violence has gained more importance in recent years. This may have been due to recent news reports on violence against healthcare workers and changes in legal regulations.

It could be seen that the highest number of keywords in the last five years was 60 for "Violence Health Workers", which is followed by "Sexual Harassment Health Workers" and "Physical Violence Health Workers" with 8, and "Verbal Abuse Health Workers" with 6. The limited number of different studies conducted on the types of violence makes it difficult for health workers to focus on risk factors and solutions for violence. According to the report (2002) named "World Workplace Violence in the Health Sector" of International of the World Health Organization (WHO), International Labor Organization (ILO) and the International Council of Nursing (ICN), most of the violence incidents occur in the health sector $(8,10,11,12)$. In this report, when violence rates against health workers in different countries are examined, in general, it was reported that $3-17 \%$ of 
the employees were physically, $27-67 \%$ were verbal, $10-$ $23 \%$ were psychological, $0,78 \%$ were sexual, $0,8-2,7 \%$ were subjected to ethnic violence. The frequent occurrence of judicial incidents against health workers in health institutions, trade unions, non-governmental organizations, social media reactions and the understanding of diversity management, increased awareness of women's rights and the enforcement of legal forces may have increased the number of physical and sexual violence studies. However, it is seen that the same interest towards verbal violence is not aroused.

Verbal violence is defined as behaviors such as intimidation, punishment, shaking confidence in the subjects that are valued, mobbing, rejection, terrorizing, degrading, exploiting, adultifiying on a regular basis. Verbal violence is not reported as much as the intensity of physical violence. According to Michaud (1994), in order to see the intensity of violence, what is violence within the institutional and legal norms should be determined, records and statistics should be kept and their control should be neutral. In order to determine the intensity of special violence in health institutions awareness should be created for the definition of violence and systems and approaches should be developed to monitor the reporting and statistical attitude towards violence.

According to Çetin (2011), Dilmaç (2009) ve Ekşi (2012) cyber bullying is quite common in Turkey. New studies are needed to determine the risk factors of cyber violence and develop solutions. While negative news intented for the health care personnel is continuously brought up in the media, not punishing the criminals who use violence (or not bringing up the results) makes us think that it legitimates the behaviour of the violence and that the viewers use violence against the health care personnel more easily. Özyurt et al. (2009) "How to prevent violence against physicians?" workshop reached this conclusion according to the survey results (16).

When examined in terms of the language used in the articles studied, the results indicate that $91,76 \%$ of them were in English. What should be highlighted is that most of the studies conducted have six and above authors (25) and the $29,76 \%$ of all of the articles in the study were multiauthored. In case of articles written by multiple authors, authors having different viewpoints come together and evaluate the situation from different aspects.

Studies in the field of violence to health employees were mostly carried out ABD (15), Turkey (9), China (9) ve Italy
(7). All of the studies have been carried out in developed and developing countries. People with long-term poverty, social exclusion, subculture of violence, substance addicts and mental health disorders, injures himself or others, who prefer to use violence in problem solving are stated to have higher risk of violence against health workers. 12 In the Middle East and African countries, which are less developed countries, it is suggested to conduct studies to determine the socio-cultural characteristics of violence against health workers.

Deeper information could be presented in the future studies as other studies in the field of violence to health employees are covered and analyzed in terms of various variables.

\section{REFERENCES}

1. Ayrancı Ü, Yenilmez Ç, Günay Y, Kaptanoğlu C. Çeşitli sağlık kurumlarında ve sağlık meslek gruplarında şiddete uğrama sıklığı. Anadolu Psikiyatri Dergisi 2002;3:147-54.

2. Irish Nurses Organisation. Workplace violence in the health sector country case studies research instruments survey questionnaire (ILO, ICN, WHO, PSI). Geneva, 2003.

3. Nau J, Halfens R, Needham I, Dassen T. The deescalating aggressive behaviour scale: development and psychometric testing. J Adv Nurs 2009;65(9):1956-64.

4. Aktuğ K, Hancı H. Acil serviste şiddet tehtidi-hekimin yasal sorumlulukları ve hakları (tıp ve sağlık hukuku). İzmir: Ege Üniversitesi Tıp Fakültesi, Toprak Ofset; 1999.

5. Polat, O. (2017). Şiddet. Marmara Üniversitesi Hukuk Fakültesi Hukuk Araştırmaları Dergisi, 22 (1), 1534. Retrieved from http://dergipark.gov.tr/maruhad/ issue/27591/290653

6. Estryn-Behar M, van der Heijden B, Camerino D, et al. Violence risks in nursing-results from the European 'NEXT' Study. Occup Med. 2008; 58: 107-114.

7. Dickson R, Cox T, Leather P, Beale D, Farnsworth B. Violence at work. Occupat Health Rev. 1993; 46: 22-24.

8. Annagür B. Sağlık Çalışanlarına Yönelik Şiddet: Risk Faktörleri, Etkileri, Değerlendirilmesi ve Önlenmesi. Psikiyatride Güncel Yaklaşımlar. 2010;2(2):161-173

9. Özcan N K, Bilgin H. Türkiye'de Sağlık Çalışanlarına Yönelik Şiddet: Sistematik Derleme. Turkiye Klinikleri J Med Sci. 2011;31(6):1442-56.

10. Sağlıkçalışanlarınayönelikartanşiddetolaylarınınaraştırılarak alınmas1 gereken önlemlerin belirlenmesi amaciyla kurulan meclis araştırması komisyonu raporu. Türkiye Büyük Millet Meclisi. Ocak 2013; Yasama Dönemi:24; Yasama Y111:3; Sıra Sayıs1: 454 Erişim: 17.06.2013 http://www. academia. edu/3654719/Saglik_Calisanlarina_Yonelik_Artan_Siddet_ Olaylarinin_Arastirilarak_Alinmasi_Gereken_Onlemlerin_ Belirlenmesi__Amaciyla_Kurulan_Meclis_Arastirmasi Komisyonu. 
11. Abbas MA, Fiala LA, Abdel Rahman AG, Fahim AE. Epidemiology of workplace violence against nursing staff in Ismailia Governorate, Egypt. J Egypt Public Health Assoc 2010;85:29-43.

12. Position Statement: Violence against nurses: 'zero tolerance' for violence against nurses and nursing students. The Registered Nurses' Association Of Ontario (RNAO), 2008 Erişim: 30.01.2013 . http://rnao.ca/sites/rnaoca/ files/storage/ related/4013_Violence_in_the_Workplace_Against_Nurses_ and_Nursig_Students.pdf.

13. Ekşi, F. (2012). Narsistik kişilik özelliklerinin internet bağımlılığı ve siber zorbalığı yordama düzeylerinin yol analizi ile incelenmesi. Educational Sciences: Theory \& Practice, 12, 1694-1706.

14. Dilmaç, B. (2009). Sanal zorbalığı yordayan psikolojik ihtiyaçlar: Lisans öğrencileri için bir ön çalışma. Kuram ve Uygulamada Eğitim Bilimleri, 9(3), 1291-1325.

15. Çetin, B., Eroğlu, Y., Peker, A., Akbaba, S. ve Pepsoy, S. (2012). Ergenlerde ilişkisel-karşıllıklı bağımlı benlik kurgusu, siber zorbalık ve psikolojik uyumsuzluk arasındaki ilişkinin incelenmesi. Kuram ve Uygulamada Eğitim Bilimleri, 12(2), 637-653.

16. Özyurt A, Ogan H, Solakoğlu Z, Bilen A ve ark. Hekime yönelik şiddet nasıl önlenir çalıştayı anket sonuçları. İstanbul Tabip Odas1 2009. Erişim: 17.06.2013. 